\title{
A Prototype of Track Gauge and Cant Measurement Device for Curved Railroad by Using Microcontroller
}

\author{
Rony Alvin Alfatah \\ Line Building Engineering and Railways \\ Indonesia Railway Polytechnique \\ Madiun, Indonesia \\ rony.tbjp1624@taruna.ppi.ac.id \\ Dwi Samsu Al Musyafa \\ Line Building Engineering and Railways \\ Indonesia Railway Polytechnique \\ Madiun, Indonesia \\ dwi.tbjp1608@taruna.ppi.ac.id
}

\author{
Wahyu Tamtomo Adi \\ Line Building Engineering and Railways \\ Indonesia Railway Polytechnique \\ Madiun, Indonesia \\ tamtomo@ppi.ac.id \\ Septiana Widi Astuti \\ Line Building Engineering and Railways \\ Indonesia Railway Polytechnique \\ Madiun, Indonesia \\ septiana@ppi.ac.id
}

\begin{abstract}
The purpose of this study is to create a tool for measuring track gauge and cant in the curved railroad with digital systems which can improve railroad maintenance with an automatic recording system for more efficient and easy to use. This tool uses Arduino IDE as an application programming language and microcontroller board combined with several sensors to measure many parameters of track gauge and cant. Android devices with a Wi-Fi connection can display the measurement results display real-time data on the screen and convert the data as a text delimited file.
\end{abstract}

Keywords: track gauge measurement, cant measurement, measurement tools, track maintenance, Arduino Uno

\section{INTRODUCTION}

The development of railroad technology in Indonesia at this time is very rapid. Technology has been developed to use the Internet of things (IoT) to make all devices can be connected wirelessly. The technology can be applied to carry out maintenance of infrastructure components and facilities, which is very important for railroad operations. The condition of infrastructure and facilities must be in good condition, safe, and secure for train operation [1].

Testing, inspection, and maintenance of railway infrastructure according to Indonesian Law No. 23/2007 are compulsory [2]. Inspection of railway track automatically can be carried out by using measuring train that equipped with an automatic recording system; it can also use a manual device such as track meter gauge can be used to measure track gauge manually.

The android operating system has been widely used in today's electronic devices and is considered easy to operate, the advantages combined with the Arduino microcontroller, which can be programmed for measurement methods. The source of development is open source which is free to develop to meet the needs [3]. Therefore, Arduino based device can be used to carry out measurement of the distance between the inner side (gauge sides) of the heads of the rails (track gauge) and the difference in elevation between the outer rail and the inner rail which is called can't on the railroad curvature using a vernier caliper sensor and gyroscope to get the parameters of the track gauge, cant of the arch, and the temperature of the measuring instrument. The data can be processed and monitored directly through an android device using node MCU as a liaison of an android device with a measuring instrument via wifi connectivity.

The use of a vernier caliper sensor and gyroscope sensor on Arduino microcontroller may give better accuracy than reading the results of measurement by using meter gauge manually. Vernier caliper and gyroscope that move on the base of the railhead will have detailed calculations up to 0.1 $\mathrm{mm}$ can determine the wear of the railhead by comparing the measurement results of the rail width with standard and tolerance for a railroad in Indonesia.

\section{RESEARCH METHOD}

\section{A. Methodology}

The method for this research starts from the formulation of the problem, formulate the objectives, collecting primary and secondary data, and analyze processed data to produce conclusions and suggestions as in Fig. 1.

This tool is used to measure the track gauge and its cant in a curved railroad by using a Vernier Caliper sensor and a gyroscope sensor controlled by a microcontroller, and the tool will send data to the application on the Android device via a Wi-Fi connection. The software system will display the results with an accuracy of $0.01 \mathrm{~mm}$. The methodology of this study as on the following figure. 


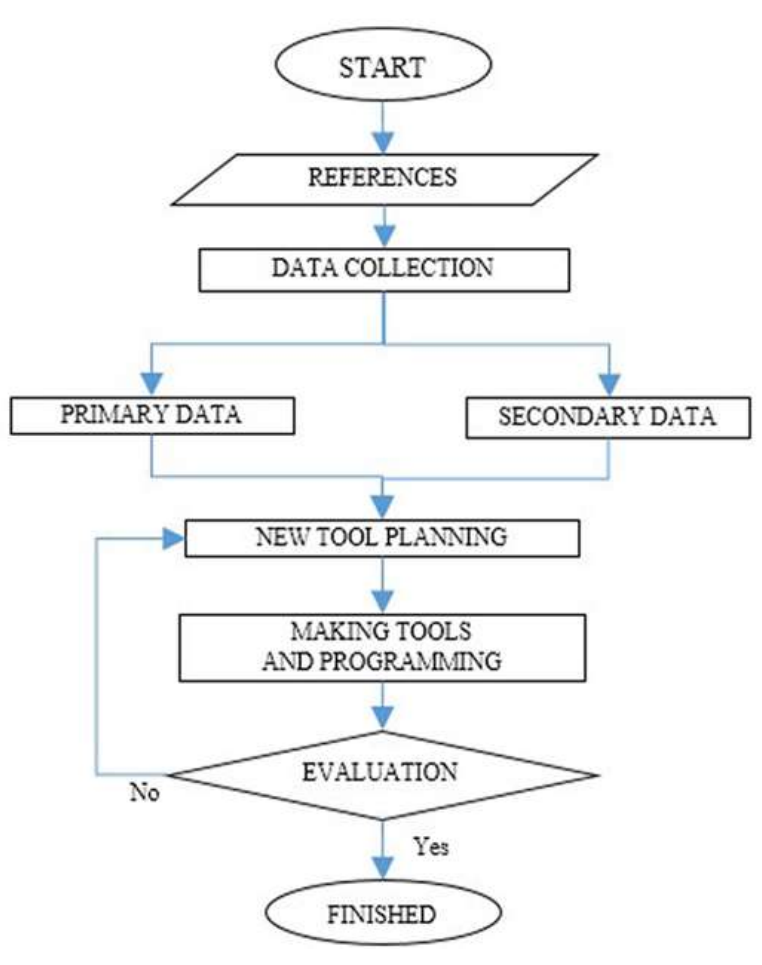

Fig. 1. Methodology.

\section{B. Programing Algorithm}

In the designing process, data collection was made on the specifications of the sensors used, library coding in the Arduino IDE application, making electronic schemes with fritzing applications, and connectivity using node MCU. After designing and installing sensors on the device, the Arduino IDE application is programmed as on Fig. 2 starting from reading, encoding, displaying and saving the results. The process continued by testing the tool to evaluate the performance.

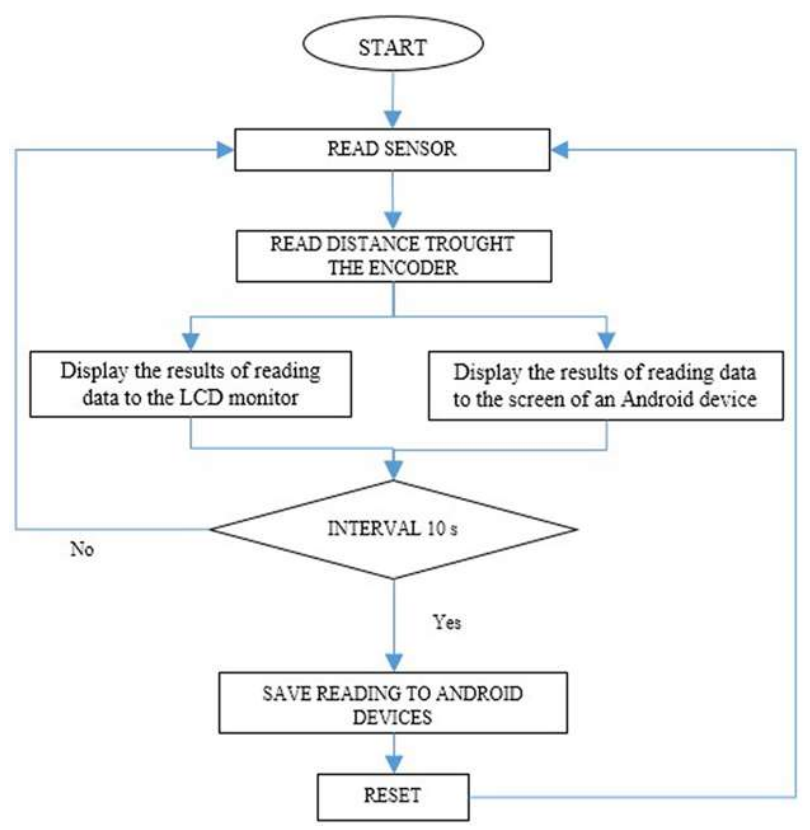

Fig. 2. Programming Algorithm.

\section{DEVICE SPECIFICATION}

The tool can measure track gauge and cant in both straight and curved paths and can show the temperature of the tool. The specifications of components and sensors used as in TABLE I.

TABLE I. SPECIFICATION

\begin{tabular}{|c|c|c|}
\hline \multicolumn{2}{|c|}{ Specification } & \multirow{2}{*}{$\begin{array}{l}\text { Information } \\
\text { wifi } 802.11 \mathrm{~b} / \mathrm{g} / \mathrm{n} \text {, } \\
\text { hotspot }\end{array}$} \\
\hline NETWORK & WLAN & \\
\hline & Kind of connection & TCP \\
\hline \multirow[t]{4}{*}{ DISPLAY } & LCD Monitor & \\
\hline & Number of characters & $4 \times 20$ digit \\
\hline & Sreen Resolution & $66 \mathrm{~mm} \times 16 \mathrm{~mm}$ \\
\hline & Android Device & N/A \\
\hline ORDER & Dimension & $104 \times 47 \times 15 \mathrm{~cm}$ \\
\hline BATTERY & Powerbank & $10000 \mathrm{mah}$ \\
\hline \multirow[t]{8}{*}{ MEASUREMENT } & Track Width & \\
\hline & Track type & $1067 \mathrm{~mm}$ \\
\hline & Resolution & $0.01 \mathrm{~mm}$ \\
\hline & Maximum aperture & $-10 \mathrm{~mm} \mathrm{~s} / \mathrm{d} 100 \mathrm{~mm}$ \\
\hline & Reading system & Digital Long term \\
\hline & Elevation & \\
\hline & Temperature & $-40 \mathrm{~s} / \mathrm{d} 85^{\circ}$ Celsius \\
\hline & Reading system & Mpu9250 \\
\hline \multirow[t]{2}{*}{$\begin{array}{l}\text { RECORDING } \\
\text { SYSTEM } \\
\end{array}$} & Data storage & File.txt \\
\hline & Reading system & TCP telnet terminal \\
\hline \multirow[t]{2}{*}{ PLATFORM } & Mikrokontroller & Arduino Uno \\
\hline & Wifi & NodeMCU esp 8266 \\
\hline \multirow[t]{2}{*}{$\begin{array}{l}\text { ADDITIONAL } \\
\text { FEATURES }\end{array}$} & Holder & 1 unit \\
\hline & Main-hole & 1 hole \\
\hline
\end{tabular}

The sensor is tested to determine the level of accuracy for the measurements. Sensor testing is conducted by measuring on the calibration frame to determine the standard zero point of measurement. The calibration frame is made with the standard narrow gauge width. In this test, the sensor measures the calibration frame and compares it to the gauge $1067 \mathrm{~mm}$.
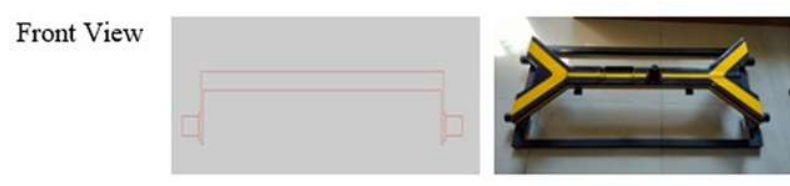

Top View
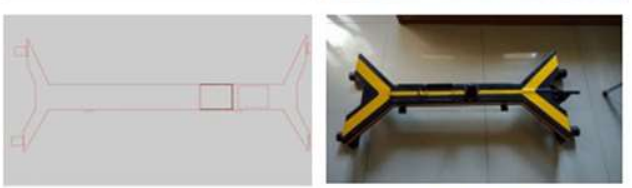

Left View
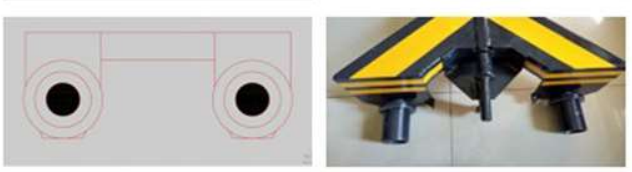

Right View
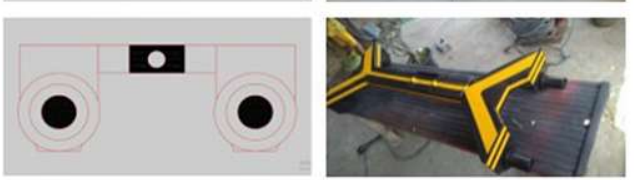

Fig. 3. Structure of the Prototype. 
Fig. 3 shown the structure of the prototype from the drawing process and after the manufacturing process in the workshop.

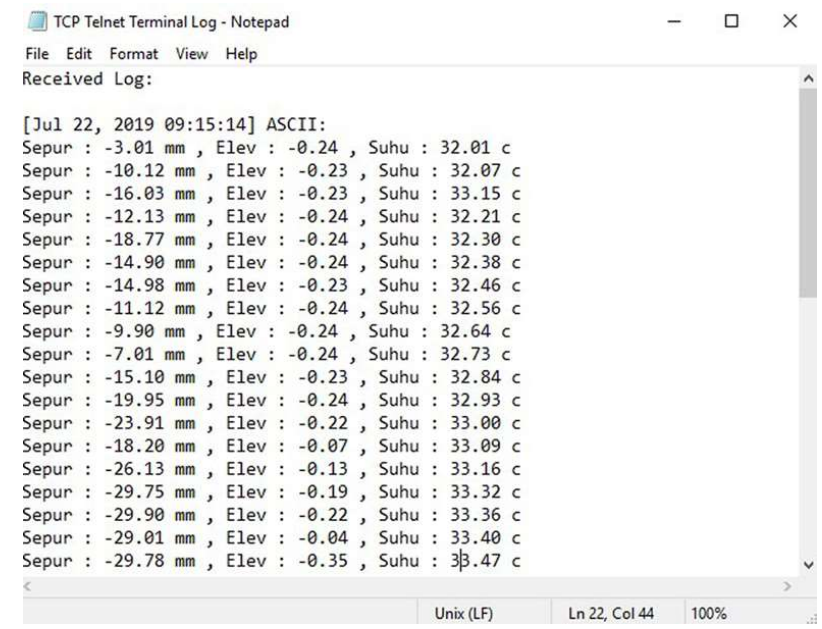

Fig. 4. The Measurement Result in .txt file.

Measurements in this test used a frame with length 1067 $\mathrm{mm}$ inside frame built with hollow steel with $1.5 \mathrm{~mm}$ thickness [4]. The average value of the test results must be zero. Furthermore, calculating the elevation value during calibration must be at the number 0.0. From the sensor testing process obtained data in the form of a table as previously shown in Fig. 4. According to the standard for the $1067 \mathrm{~mm}$ narrow gauge the tolerance for track width or track gauge is $+2 ; 0$ for new track and $-5 ;+2$ for the existing track [5] the device will read the plus or minus from zero (0) point as a widening or narrowing of track gauge. Railroad maintenance is carried out to maintain the road conditions in accordance with the operating standards of the railroad to serve railway facilities according to the Rail Road Quality Index value (Track Qualify Index) that has been set.

\section{WORKING PRINCIPLE}

The tool is designed to take measurements on the curvature of the railroad as well as on a straight track. The device is calibrated before it is used to carry out measurements and the digital calipers inside the main hole are set, so the device is at zero position (0).

The slide is connected to an iron bar which has a small wheel that measures the inside edge of the rail $14 \mathrm{~mm}$ below the railhead. This measurement is conducted by moving the tools manually along the track.

The measurement data obtained and then recorded by the processing box and displayed on the LCD monitor and the Android smartphone screen via the TCP-Telnet application to record the measurement result. The process of recording the measurement results is completely automatic and can be downloaded in the form of a text (.txt) file that has been neatly arranged according to the measurement parameters.

Adjustment of the equipment must be carried out before the measurement to make sure the tool works properly. This step takes about 2 minutes and can be handled by 1 trained person. The following are the steps to adjust the tool:
- Connect the mechanical components with the processing box with the cable connector on the mechanical components with the side of the processing box.

- Connect to the power source (power bank) and the processing box will automatically turn on and activate wifi.

- Create a hotspot with the name and password listed on the LCD screen using an Android smartphone, and the device will automatically connect.

- Calibrate the tool and reset the sensor by installing the tool on the calibration tool and reset the digital calipers by pressing the zero button inside the main-hole so that the tool will start with the width of $1067 \mathrm{~mm}$ on the track as a zero point of measurement.

- Install the tool on the track by positioning the wheels between the two rails and pushing the measuring wheel lever so that the wheel can enter the inside of the rail track.

- Install the stick in the center where two hinge holes are available. Insert the thread section of the pusher stick into the hinge and lock it with a nut to keep it from sliding or sliding when pushing the tool.

- Open the TCP Telnet application in the smartphone application then enter the port and IP address shown on the screen.

- Measurements are made by pushing the tool by walking on the track, and the data has been automatically recorded in the application. Recording of measurement data can be seen on the Android screen and LCD monitor.

- When the measurement is completed, select the vertical triangle menu in the upper right corner of the TCP telnet interface and select "send logfile."

- Data can be saved by sharing them via social media and sent directly to the recipient or can be stored directly in the form of file.rar or file.zip using additional applications that can be downloaded at Playstore.

- Further data processing can be processed in Microsoft Excel.

- The device can be turned off by unplugging the USB cable from the power bank.

- Remove the electronic components in the mechanical components and store them in safe storage.

\section{A. Device Testing}

Testing the measuring instrument is a step that must be carried out to look for obstacles or problems that might occur in the working system of measuring devices while ensuring all measuring systems can work properly. The testing track gauge and cant of the railroad are carried out on the track laboratory in Indonesian Railway Academy Madiun, to compare track gauge and cant by using meter-gauge (Matissa) and this device. The measurement results using a meter-gauge (Matissa) proven to have accurate results, 
therefore the comparison of measurement results using a meter gauge. The track is measured by a Matissa and by the device at the same point along 100-meter track length to get 30 points of measurements. The test is conducted as on the Fig. 5.

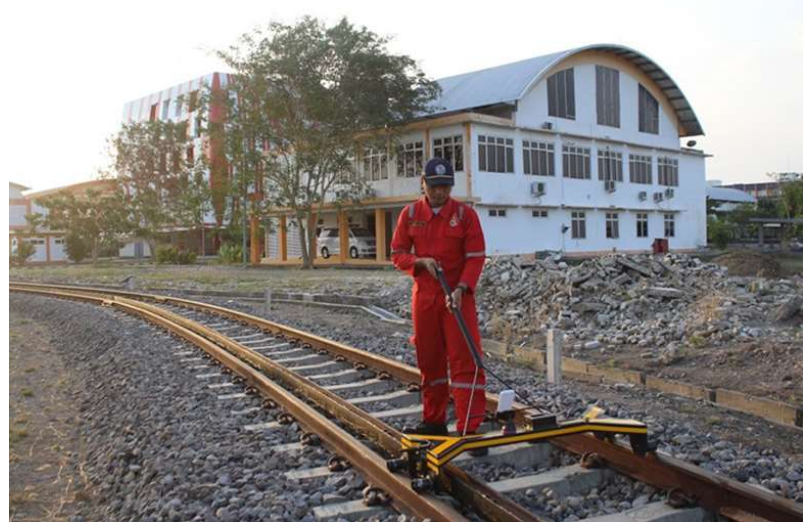

Fig. 5. Prototype Testing on Track.

The results for time needed to get measurement data showed that by using the prototype needed 6.93 seconds to measure one point on a straight railway line and 8.17 seconds to measure curved one, whilst by using track meter gauge (Matissa) it needed 34.5 seconds to measure one point and 60 Second to measure one point on a curved one. These results suggested that this device produce 13 to $20 \%$ measurement time efficiency.

TABLE II. MEASUREMENT RESUlt AND ACCURACY

\begin{tabular}{|l|l|l|l|}
\hline No & \multicolumn{1}{|c|}{ Measurements Type } & $\begin{array}{c}\text { Average Differences } \\
(\mathbf{m m})\end{array}$ & Accuracy \\
\hline 1. & Gauge on Tangent Track & 0.44 & $99.96 \%$ \\
\hline 2. & Gauge on Curved Track & 0.53 & $99.95 \%$ \\
\hline 3. & Cant on Curved Track & 0.59 & $97.77 \%$ \\
\hline
\end{tabular}

The results for track gauge and cant between track meter gauge (mantissa) and the prototype is compared as in TABLE II show that the new prototype can measure gauge and cant accurately compared to standard track meter gauge device.

\section{B. Result And Analysis}

The prototype is made based on specifications for narrow track gauge $1067 \mathrm{~mm}$ which can be used to measure widening and cant at railway curve following the railway track specification from Ministry of Transportation Regulation PM No. 60/2012 [6].

The results and evaluation of the design, data collection, the results from Arduino-Android based prototype measurement device is compared to track meter gauge as on TABLE III. The table shown comparison by several indicators: accuracy, price, location, mobility, and accuracy. In general, the prototype provides more benefit than the standard track meter gauge.

The Prototype can measure track gauge and cant in the railway accurately. The sensor can be adjusted with the field conditions, especially when attached to the surface of the rail-head. The output of the examination results in the form of numerical data which can directly be via LCD (Liquid Crystal Display) located on the mechanical components of the tool or can be accessed on the smartphone application. The results of inspection data can be accessed easily by the available android application.

The prototype has not proven to be waterproof, the sensor on the device is prone to water, and the weight of the device is 5 times the standard meter-gauge. And the body was made by galvanized steel with varnish paint additional coating.

TABLE III. PROTOTYPE COMPARISON

\begin{tabular}{|l|l|l|}
\hline Indicator & \multicolumn{1}{|c|}{ Meter gauge } & \multicolumn{1}{c|}{ Prototype } \\
\hline $\begin{array}{l}\text { Accuracy } \\
\text { reading }\end{array}$ & $\begin{array}{l}\text { Readings made on the } \\
\text { Matisa tool or } \\
\text { Metergauge are still } \\
\text { done manually so that } \\
\text { the possibility of errors } \\
\text { in the reading by human } \\
\text { errors or the accuracy of } \\
\text { the tool can still occur. }\end{array}$ & $\begin{array}{l}\text { The reading is done digitally, } \\
\text { and the results of the } \\
\text { measurements are directly } \\
\text { printed on the LCD and can be } \\
\text { accessed in the smartphone } \\
\text { application, so there is no } \\
\text { mistake between one reader } \\
\text { and another reader. }\end{array}$ \\
\hline Price & $\begin{array}{l}\text { The price of the Matisa } \\
\text { or Metergauge is higher } \\
\text { with an estimated price } \\
\text { of around 5-9 million } \\
\text { rupiahs. }\end{array}$ & $\begin{array}{l}\text { The price of the tool is much } \\
\text { lower than the Matisa or } \\
\text { Metergauge with an estimated } \\
\text { price of not reaching 4 million } \\
\text { rupiahs. }\end{array}$ \\
\hline $\begin{array}{l}\text { Location } \\
\text { of Use }\end{array}$ & $\begin{array}{l}\text { Can be used on straight } \\
\text { and curved tracks } \\
\text { without check/guard } \\
\text { rail. }\end{array}$ & $\begin{array}{l}\text { Can be used on straight tracks, } \\
\text { curved railroad tracks with } \\
\text { check/guard rail. }\end{array}$ \\
\hline Mobility & $\begin{array}{l}\text { The tool can only be } \\
\text { used manually by lifting } \\
\text { to measure at each point }\end{array}$ & $\begin{array}{l}\text { The tool can be used manually } \\
\text { or using methods encouraged to } \\
\text { obtain data results at each } \\
\text { measurement point }\end{array}$ \\
\hline $\begin{array}{l}\text { Tool } \\
\text { Accuracy }\end{array}$ & $\begin{array}{l}\text { Having a reading } \\
\text { accuracy value of } \\
\text { 0.5mm }\end{array}$ & $\begin{array}{l}\text { The level of accuracy of the } \\
\text { reading of 0.1mm }\end{array}$ \\
\hline
\end{tabular}

\section{Conclusions And SugGestions}

The measurement device prototype for track gauge and cant have been developed by using recent development of technology which can continuously obtain data, record and display the results on other device. The tool has several advantages by being more accurate, can reduce human error in reading the results, has a lower price, and can be used in curve with guard rail.

To use the device on a long time need further improvement on the calipers because it used battery and the sensor can run out of power in the middle of use. The sensor is vulnerable to water, so it does not allow the tool to be used in rainy conditions on the site. The device should be protected so that the sensor can be used even in rainy conditions.

The prototype is expected to be improved both in design and function for further development before it can be manufactured and used in railway track operation and maintenance.

\section{REFERENCES}

[1] Surakim. H, Railroad Construction and Railroad Travel Safety (in Indonesian). Nuansa Cendekia. Bandung, 2014.

[2] Government of Republic of Indonesia. Law number 23 of 2007 concerning Railway (in Indonesian). 
[3] Oby, zamisyak, "Arduino's Hero," Indobot Robotic Center (In Indonesian). Yogjakarta, 2018.

[4] Purnama. Rizal, Hollow Steel (In Indonesian). http://rizalarchie.blogspot.com/2013/03/besi-holo-besi-hollow-sangatbaik.html.

[5] Ministry of Transportation. Ministrial Regulation number 32 of 2012 Standards and Procedures of Infrastructure Maintenance (in Indonesian).

[6] Ministry of Transportation Ministrial Regulation number 60 of 2012 concerning Technical Spesification of Railway Track (in Indonesian). 